\title{
Gravel and boulders mining from mountain stream beds
}

\author{
Artur Radecki-Pawlik ${ }^{1, *}$, Anna Kidová $^{2}$, Milan Lehotsky², Miloš Rusnák², \\ Russell Manson ${ }^{3}$, Bartosz Radecki-Pawlik ${ }^{1}$ \\ ${ }^{1}$ Cracow University of Technology, Faculty of Civil Engineering, Krakow, Poland \\ ${ }^{2}$ Slovak Academy of Sciences, Institute of Geography, Bratislava, Slovakia \\ ${ }^{3}$ School of Natural Sciences and Mathematics, Stockton University, NJ , USA
}

\begin{abstract}
Mountain stream gravel is very often legally and illegally mined and gravel is removed from river beds sometimes on the very large scale which is disastrous for fluvial situation of rivers, for river ecology and river engineering works done for flood protection such as river revetments, bridges and all hydraulic structures. This situation makes a big problem for all river managers. Thus gravel mining of the mountain streams in the Polish Carpathians is the subject of many scientific studies when we observe river problems, but also it has a place in Slovakia. This paper deals with such problems additionally showing examples of such bad practices.
\end{abstract}

Keywords: mountain stream, gravel mining, river bed, Carpathians

\section{Introduction}

One of the essential factors affecting the way in which the mountain rivers and streams flood, is bed and bank stability. This stability depends on the condition of the gravel cover lying on stream beds, so-called stream bed armouring. The better the armouring of a mountain stream, the smaller the probability of the stream breaking its banks during flooding, and, as a result, the safer the channel of the stream [1, 2, 3, 4]. Sediment mining in alluvial channels: physical effects and management perspectives. Unfortunately, there has recently been more and more cases of uncontrolled digging of gravel and boulders out of mountain stream channels. This results in catastrophic damage to the stability of stream beds and banks $[3,5]$.

In that case, the sediment removing from the river channels supports the river adjustment to new hydraulic and morphological conditions. Generally, in case of Slovakian case studies, we can distinguish between gravel mining directly in the low flow active

\footnotetext{
*Corresponding author: rmradeck@cyf-kr.edu.pl
} 
channel and on the part of floodplain area besides channels. The river response on this kind of interventions on the initially natural river system with decreased volume of sediment related with multiplied water energy concentrated in active channels. Gravel mining directly from channels caused negative morphological responses of the river system on the several connectivity levels (channel-bed, channel-bank and channel-floodplain). Predominant vertical erosion was during high discharges usually accompanied by intensive bed wash-out. Acceleration of the bed erosion processes led to deepening and narrowing of the river channels. After downstream transport of the last remaining sediment, the river channel started incise to the bedrock as a hungry water consequence. Hungry water means, that water with lack of sediment has higher tendency to pick up sediment. This lead to increasing in-channel erosion processes. One flood event with sufficient high magnitude of discharge ( $>20$-years RI) or several smaller consecutive floods (5-10-years RI) well supported expansion of the defecting vertical erosion in upstream direction as consequence of backwater erosion. In addition, the straightening of the low flow channels led to disruption of the dynamic structure of the channel morphology (e.g. island area growth) as well as decrease its ability to further lateral bank erosion. On the connectivity channelfloodplain level the river system lost important lateral eco-hydrological connectivity with side floodplain area. Gravel mining activities concentrated more to floodplain area affected the further morphological processes mainly during high discharges (floods) and decrease ecological values. Changed topographic floodplain structure by mining mechanisms developed the predisposition for frequent formation of the new avulsion channels during floodplain inundation supported by the presence location of mining pits.

In this paper we present some examples of mountain stream bed degradation in Poland and Slovakia. For Polish part of the analysis we have chosen the streams in the Zawoja village region. These are the Czatożanka and Jałowiecki streams which, together with the Jaworzynka stream, form the Skawica river. In addition, we wrote this part of the text immediately after the tragic consequences of floods in the Suski region (Zawoja village is located in this region) which could be witnessed by the authors whilst taking hydrological measurements during the flood in the last ten days of July in 2010.

As the second three examples for our analysis we chosen the braided-wandering Belá River and two sinusous laterally active the Topl'a and the Ondava River from north-east Slovakia. Gravel mining was legally connected with these river systems in near history as well as in presence. In addition, the one of them, the morphologically specific and rare the Belá River was exposure to morpho-ecological devastation by safeguarding works related with sediment mining and movement after flood event (5-years RI, 19.7.2018) during last summer.

\subsection{Case study from Poland}

\section{Jalowiecki stream in Zawoja - illegal gravel mining}

In order to understand why gravel and boulders cannot be exploited with impunity, one has to answer the question of where gravel and boulders in streams come from. For the period of the last $1.5 \mathrm{~m}$ years (in geology. this period is called the Quaternary) and especially for the period of the last 11000 years (in the Holocene Epoch) streams which have their sources on the slopes of Babia Gora carry a bed load of gravel and boulders. Gravel and boulders of various sizes are transported by streams during high waters. Streams, in their steepest sections located near their sources, act as gullies in which the material eroded from the massif is carried down to lower sections of streams. Gravel and boulders are then moved to a stream region with much smaller degree of steepness than in 
the stream source region. The transport of gravel takes place along the steepest section of the stream, for instance, in the Jałowiecki stream, it is from its source to the so-called Małe Widły in Zawoja Składy and in the Czatożanka stream, the steepest section is from its source to Zawoja Czatoży.

The transport of sediment (grains of the size of 1-2 $\mathrm{mm}$ to 19 or more $\mathrm{cm}$ ) takes place during high waters. When the stream bed slope falls suddenly, the transported gravel and boulders are deposited. This process also occurs in streams in the Zawoja region. Transported material from Babia Góra is deposited as bars and alluvial fans in the lower regions of the Jałowiecki stream, the Czatożanka stream and the Skawica river. The transport of the material lasts until the stream stabilises, that is, until the stream has a bed slope that provides the balance between the stream or river strength and load. In theory, a river which has reached its equilibrium profile neither erodes nor accumulates its bed load; it only transports it. Thus, the river strength is enough to transport the bed load (this results from the so-called river equilibrium curve which can be prepared for each stream). Although, in reality this equilibrium is unstable, in practice only large floods can disrupt it. The mechanism of bed load transport down the stream, then down the river and into the sea is continuous and the bed load is broken down so that boulders change into cobbles, cobbles change into pebbles and pebbles change into sand.

Let us stop at the moment when the first gravel and boulders start being deposited right below the steep sections of streams. In the discussed example in the village of Zawoja, the material is deposited in the region of Małe Widły. Some of the material stays in that section, the rest, probably the excess of the material, is transported to the lower sections of Skawica. Gravel formations of streams and rivers deposited by their waters and left on these sections are called alluvial deposits. Along the sections where the bed load is deposited, the stream erodes only in its own alluvia and forms various kinds of channel forms, mainly bars. At the same time, except for the creation of the above-mentioned condition of equilibrium in the longitudinal profile of the stream, the natural armouring is formed on the channel bed. Gravel and boulders lying on stream side bars protect its banks naturally. They are compact and often very durable. Boulders lying in a channel resemble the layout of tiles on a house roof and they naturally strengthen the stream bed(referred to as bed imbrications). Thus, stream equilibrium is achieved in which the stream itself forms such an armoured bed that it can with stand short-term high waters. Of course, when the catastrophic one-hundred-year flood occurs, this armour is destroyed and we cannot protect ourselves from it. We have to be aware that there are no river training structures that can protect us from such floods, with the possible exception of huge storage reservoirs.

Another question that may be asked concerns what happens to the stream bed which is in some kind of an optimal condition when we remove some gravel from the section where a significant bed load was deposited - the answer is not explicit. Everything depends on the amount of bed load that is removed and from which section of the stream it is removed. It is well known that human settlements have always been connected with rivers and streams. Since people started building houses, the main building material was not only wood but also stone and gravel and the easiest way of getting this building material seemed to be digging it out of stream beds. Such activities took place in the Zawoja region until the year 1939. However, most of the building material was acquired from quarries. There were two quarries in the Zawoja region. Taking gravel from streams was sporadic and boulders were used only to decorate the underpinning of houses. However, there is a difference between the amount of gravel used before the Second World War and the amount of gravel used now. At the beginning of the twenty first century, along the abovementioned section of the Skawica stream in Zawoja Górna, there were between ten and twenty houses. Even when we take into consideration the whole Zawoja region until the year 1945, there were only a few hundred buildings. If each farmer had taken two carts of stones from the stream to 
build their houses, then, for example, for 800 houses they would have taken together $2 \mathrm{x}$ $400 \mathrm{~kg}$ x $800=640$ tonnes of boulders and gravel. The stream can replace this amount of material over a period of 50 years.

After the year 1945, the development of reinforced building industry caused a rapid demand for gravel. Mass exploitation of gravel and especially boulders began. Boulders were used mainly for foundations and because the means of transport and excavation have changed, the bed material was dug out on an unprecedented scale. If instead of two carts, we take three 6 to 8 -tonne dumper trucks, then for 4000 houses (this is the current number of houses in Zawoja),96 000 tonnes of bed material have been taken from the stream over the last 50 years. Such an amount of bed load cannot be replaced in even 500 years.

From the author's calculations, it appears that the transport of bed load in Czatożanka and Jałowiecki streams region was about 14000 tonnes after the year 1950. This means that from the channels of the discussed streams, much more gravel was removed than reached the Małe Widły region. What does this mean for the stream channel? As mentioned above, streams tend to reach some kind of equilibrium and such an equilibrium is generated after the bed load is taken out of the stream (Fig. 1). When a stream doesn't receive enough bed load from Babia Góra, it starts to erode its own bed and banks. Next, it starts to cut into the bed deeper and deeper, often through gravel formations and rock stratum. This means that the stream is deprived of its protective cover - the previously mentioned armouring - it is like a skinned living organism. The consequence of such a condition is the Jałowiecki and Czatożanka streams cutting into their beds to a depth of approximately $80 \mathrm{~cm}$ in some places, even over $1 \mathrm{~m}$ over the period of the last 50 years (on the basis of the author's estimated calculations, observations and field interviews).
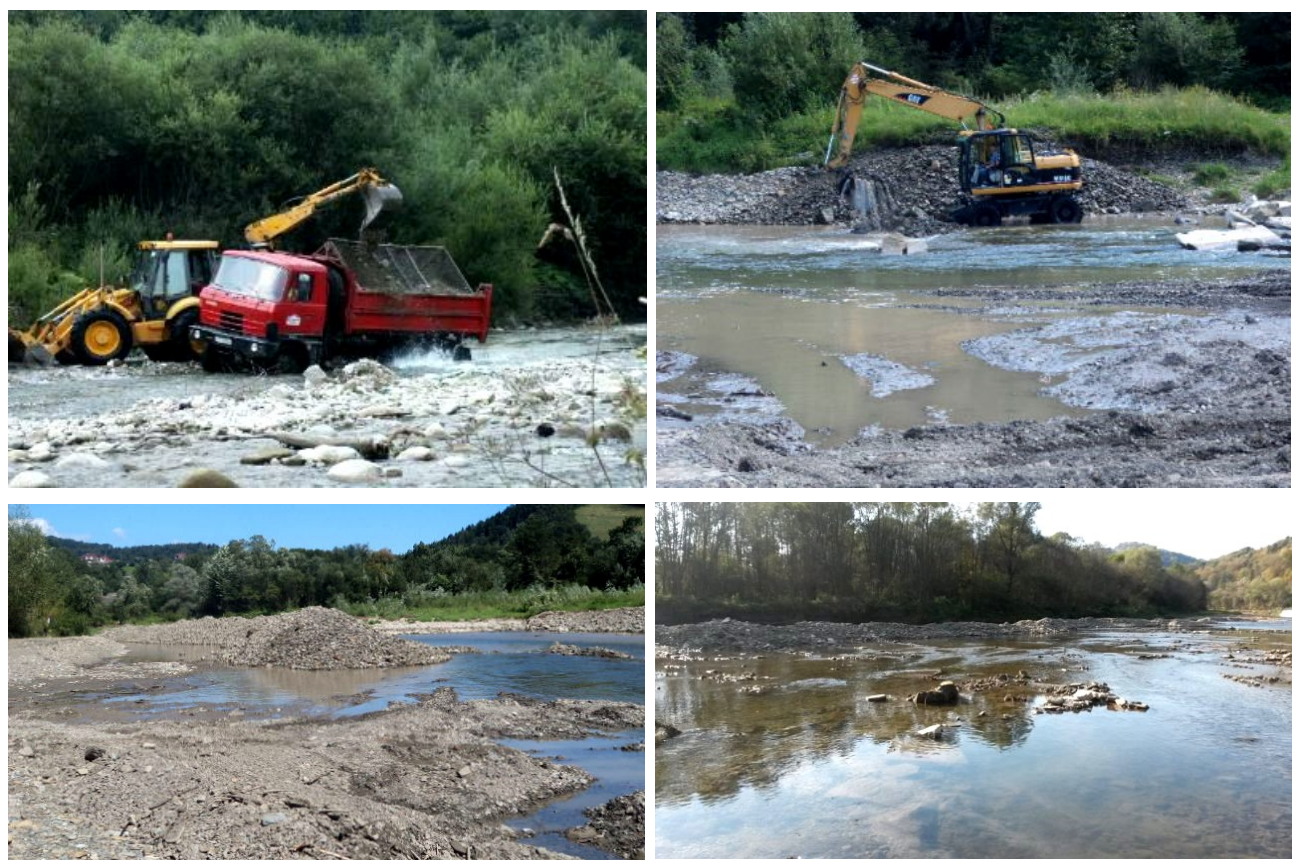

Fig. 1. Illegal gravel mining in Polish Carpathians: excavators and lorries in work and river gravel bed degradation after illegal gravel activity

Another problem connected with taking gravel and boulders from mountain stream channels is the destruction of river training structures. Since a stream tends to level its bed, 
it cuts into its stratum practically along its entire length. All attempts to balance the bed fail. Let us imagine, as an example, a bridge or gabion baskets along a section of a stream. Even if somebody takes gravel 1 or 2 kilometres downstream from a stream training structure or a bridge (even the load of a few dumper trucks), these structures which have their foundations and usually serve their purpose for several dozen years are immediately scoured. The bed under these structures lowers and eats into the bank, thus the structures start to overhang the stream. Recently built expensive revetments are destroyed after a few years. For the price of $100 \mathrm{~m}$ of bank revetments and a few weirs reducing the stream slope, a housing estate can be built. The same situation is with bridges. The best example is the bridge over Jałowiecki stream, upstream from the local National Park Museum, which was supported with one weir 10 years ago. Today, it is supported by a few-metre-high cascade of weirs. Another example is the gabion revetment and the bridge abutments in the region of guesthouse 'Filip' in Zawoja Wilczna. As a consequence of gravel exploitation along the section from Duże Widly upstream to the region of Old Chapelin Wilczna, and, in thespringof 2000, digging and mechanical pushing through the stream bed, the abovementioned bridge will very shortly require a support with a weir and the revetments near the 'Filip' guesthouse is already scoured. River training structures, including weirs and bridges, are designed for a specific stream bed slope. Their function is to stabilise that slope, to dissipate the energy of a river during flood, to aid the natural process of bed armouring and to secure the river channel. If the bed material is taken out from sections located downstream of the structures, these structures lose their stability and they are destroyed. As the consequence, during flood events, people may lose their possessions and even their lives and the stream changes into a wild beast destroying everything in its path.

\subsection{Case study from Slovakia}

\section{$\underline{\text { Belá River - in-channel gravel extraction }}$}

The Belá River presents very rare and valuable multi-thread river system in Slovakia affected by human impact and environmental changes. Approximately $140000 \mathrm{~m} 3$ of gravel were extracted along $7 \mathrm{~km}$ long river reach during 50 years (1950-2000) as the flood protection action for Liptovský Hrádok and Dovalovo settlements as well as for the protection of road and railway bridges [6]. This material was used for construction industry. The intensive gravel mining (continued until 2000) resulted in the upstream channel incision and extension of a knick point zone located on the system of cross-valley faults. Termination of gravel-mining activity together with the river response to the occurrence of 5- to 10-year floods in 1993-2003 led to increasing bank erosion, avulsion and chute cutoffs occurrence and lateral and vertical accretion.

Nowadays gravel extraction on the Belá River is related with stabilizing works after flood event (5-7 years RI) during summer 2018. Realization of this works were declared according the second and third degree of flood activity in the Belá River catchment and were aimed to protection of private property and citizens' lives. However, according to official documents the main reason was channel overflow what endanger the road operation. These works was aimed to removing of the gravel bar accumulation (46 $600 \mathrm{~m} 3$ planned in total), moving of the river sediment (24000 m3planned in total) and redirection of the channel course (Fig. 2). Practically, along the river length the specific morphological processes typical for the multi-thread Belá River were suppressed to minimum. Individual terrain reconnaissance in August 2018 reveals that total channel improvement overgrew the range of planned works and the channel and bed armouring was destroyed by the operation of heavy mechanisms. On the several river reaches we registered an artificial development of the new channel shape (wide "U") with concentrated water course within shallow low 
flow channel and isolated floodplain from the active channels due to $2 \mathrm{~m}$ high new artificial banks. This type of river regulation including gravel extraction and gravel replacement were also occurred on the river reaches where the residential area is missing and there was no threat to property rights and lives.
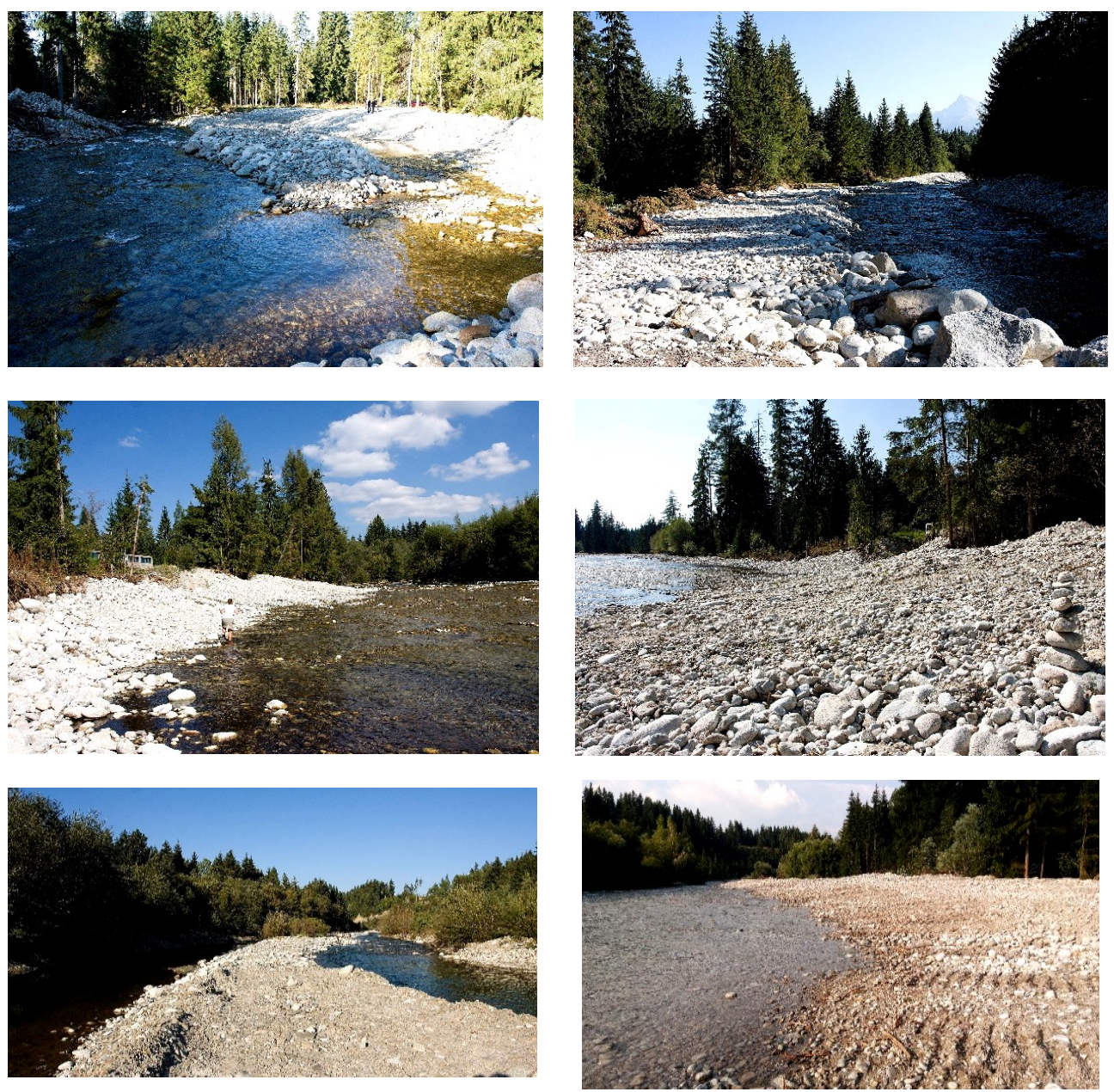

Fig. 2. River gravel bed degradation after illegal gravel activity on Slovakians rivers.

\section{Topl'a and Ondava River-floodplain and in-channel gravel extraction}

The Ondava River and the Topl'a River represent similar situation on the Eastern part of Slovakia. Here, gravel extraction was analysed based on gravel pits mapping on aerial Fig.s from 1949 to 2009. The new gravel-pit company was established between 2013 and 2014, even others gravel-pit companies are situated in the study the Ondava River near Breznica and Stropkov settlements, and near Kurime, Bardejovská Nová Ves and Bardejov settlements respectively. Based on gravel pit area identification, the largest volume of extracted gravels was found in 1981 for both study rivers. On the Ondava River the gravel pit area represented 19,52 ha and on the Topl'a River was identified area 23,22 ha of mining pit. The gravel mining during study time span 1949 - 1987was predominantly focused on 
floodplain area. Nowadays gravel extraction (2002 - 2009) is concentrating to active channel area where the volume of gravel mining is permitted by the mining license up to $1000 \mathrm{~m} 3$ per year for one company. This extracted sediment volume is aimed to restrict the sediment supply to the Domaša water reservoir. Channel bed is formed by gravel fraction (from 2 to $64 \mathrm{~mm}$ ) with average proportion $84,1 \%$ for the Topl'a River and $81,8 \%$ for the Ondava River. Average grain size D50 is for the Topl'a 33,09 mm (-5,02 Phi) and 35,23 $\mathrm{mm}(-5,08 \mathrm{Phi})$ for the Ondava. In addition to gravel extraction both rivers are lateral dynamic with intensive migration of channel. Erosion protection is ensured by channelization and artificial embankment in areas of settlements but in other section was channel modified and straighten to the original state, gravel materials are pre-load in the form of dikes near active channel without reinforcement (Fig. 3, 4).

We could conclude that gravel mining has significant influence on morphological processes during last study period (after 1987) when the formation of sinuous single-thread river pattern was registered. We can identify a several evolution phases for both rivers. The first one is channel degradation as a reaction of the climatic changes on the end of the Little Ice Age. The second one is riparian forest development (stabilization phase) between 1981 and 1987 supported by low flood activity. Extreme flood events after 2002as well as gravel mining led to intensive erosion processes (1,9 m bedrock incision on the Ondava River) and new floodplain vertical benches creation. This vertical differentiation on the Topla River is not so significant. Rinaldi et al. [2] conclude that braided rivers with higher sediment supply are more sensitive to gravel mining than sinuous and meandering river with lower sediment supply.
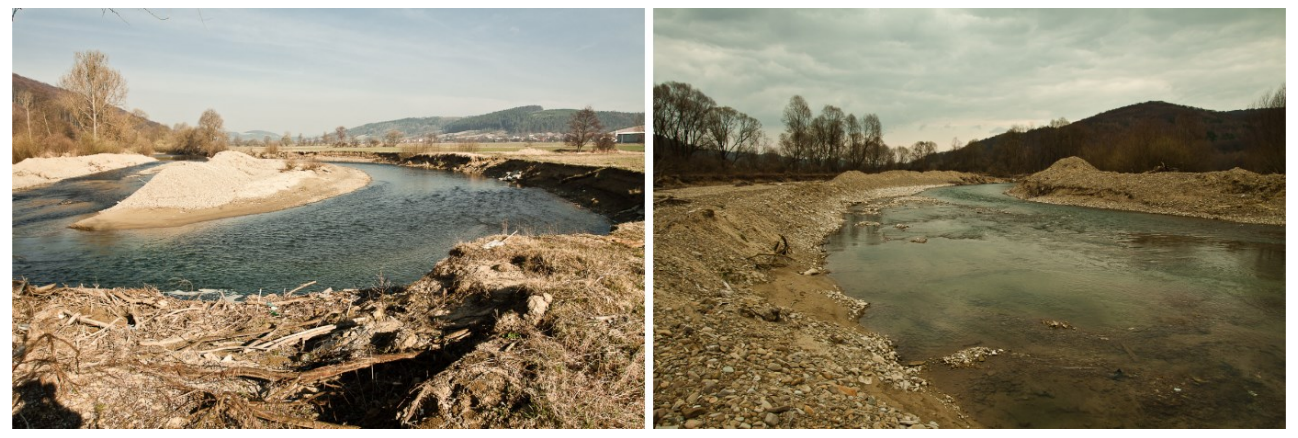

Fig. 3. River gravel bed degradation after illegal gravel activity on Slovakians rivers.
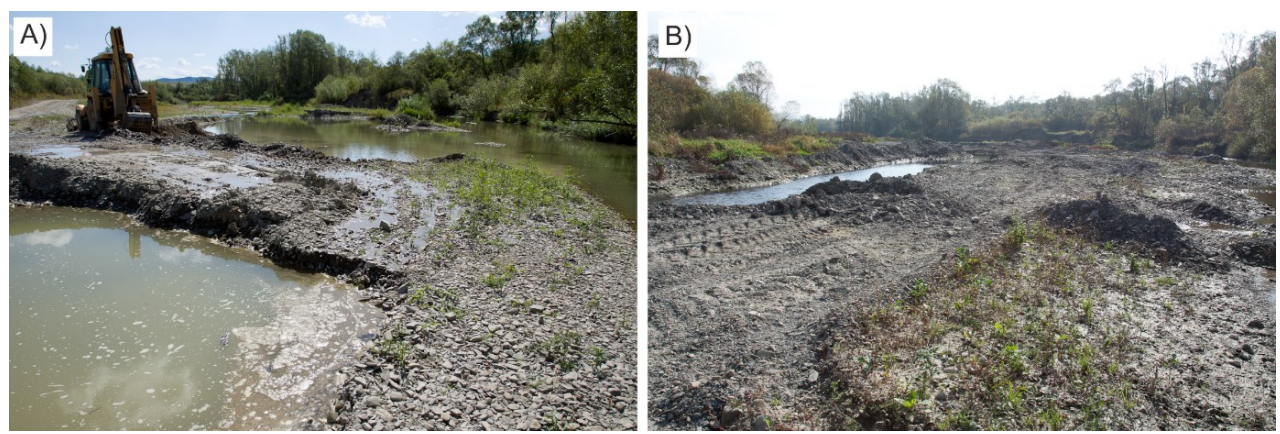

Fig. 4. Gravel mining on the Ondava River near the Breznica village (A) and channel destruction by mechanisms (B). 

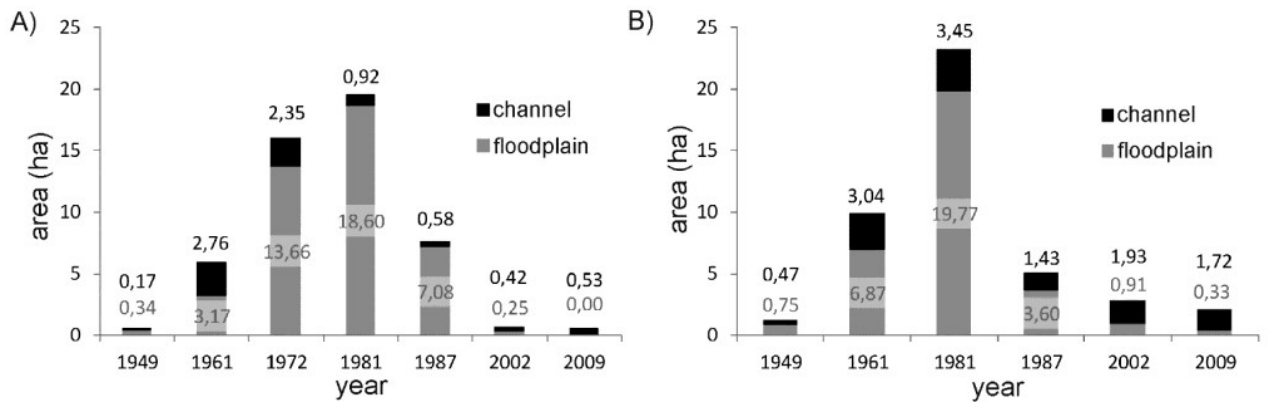

Fig. 5. The gravel pit area identified on the floodplain and active channel for theOndava River (A) and Topl'a River (B) during study time span 1949 - 2009.

The largest volume of gravel extraction, calculated on the basis of the excavation area, took place at both the Ondava River and the Topl'a River in 1981, where the gravel pit area represented 19,52 ha on the Ondava River, respectively 23,22 ha on the Topl'a River. Their area then decreased dramatically. The largest volume of mining in the study period was on the floodplain area (Fig. 5).

\section{Summary}

To summarise, the uncontrolled acquisition and mining of bed material, with or without authorities' permission, undoubtedly leads to disastrous consequences for the stream channel and the stream training structures. The stream channel is deprived of its natural protection - bed armouring. Banks of such a stream channel are scoured over a long distance and far upstream from the place where the bed material was taken out. Money spent by local authorities on stream training is wasted and stream flood protection damaged. People who have experienced the disaster caused by floods in the region of the stream basin, where the gravel is exploited on a mass scale, could not only have other elements of infrastructure built but could also avoid the total destruction of their belongings during smaller floods. An additional aspect of the uncontrolled acquisition of gravel from stream bed is the destruction of the biological life of streams; stream bed invertebrates are killed, which results in a significant decrease in the fish population.

In addition to the description of the mechanism of gravel and boulder removal from mountain streams, it is important to propose some kind of remedy for the existing situation. Should the excavation of gravel from stream be prohibited? Is it sensible, in the current economic circumstances and almost a complete sense of impunity, to Fight the uncontrolled excavation of stream bed material? We think that thorough education of villagers about the problems discussed earlier is needed. Village inhabitants should be aware of the threats that are caused by taking gravel from streams. If there are permits to take gravel introduced, they should be issued by specialists and should state the amount of gravel that can be dug out. Furthermore, the gravel should be taken under the supervision of guards or representatives of institutions which would issue such permits. Certainly, the whole procedure would be cheaper than the annual repair of stream revetments. Experts, 
preferably coming from outside of the region, must state where this gravel can be taken from and whether it should be taken at all. We think that this is possible, for example, upstream/downstream of debris dams or storage reservoirs. Somebody should perform a thorough calculation of what is more beneficial: repair of damaged stream channels, constant repair of revetments and bridge abutments, Fighting with the effects of small floods; help in aggregate acquisition and delivering it to people so that they can build their houses. All measures taken should absolutely have the same purpose - to make people aware that they harm themselves when they damage stream beds and, as a consequence, they should refrain from uncontrolled excavation of gravel from mountain streams. Overall, the constructive dialog and cooperation between experts and authorities directly responsible for flood-protection works, sediment balance, channelization, etc. offers new challenges how to address the key issues for improvement sustainability of the river management. Recommendation for the river management relates to restriction of illegal gravel mining from the active channel area which accelerate new local erosive bases with migration potential in upstream direction (backward erosion). Water and streams are the most valuable gift that nature has bestowed upon us, but if we disrespect them, they may prove to be our worst enemy.

\section{Final remarks}

On the 2nd August 2001, a few days after the tragic flood of Maków Podhalański, dumper trucks took 40 tonnes of gravel and boulders fromthe Czatożanka stream in Zawoja, just upstream of a bridge in Małe Widły. Such activities leave huge sections of banks removed measuring even up to twenty metres. This leaves us with the awareness that there might be further breaks in the stream banks upstream and that this may pose a threat to nearby buildings along the Czatożanka stream. The Czatożanka stream channel may become deeper and deeper may be by one millimetre, maybe by half a millimetre. Some people may say that this is not much, but in 50 years' time, it could be another metre.

The multi temporal analyses on the Belá River proved that the active river zone area decreased from $2,5 \mathrm{~km} 2$ with average channel width $108,1 \mathrm{~m}$ in 1949 to $1,4 \mathrm{~km} 2$ with average channel width $60,8 \mathrm{~m}$ in 2009 due to changed environmental condition (decreased recurrence interval of floods, land use and land cover in catchment, anthropogenic influences) $[7,8]$. The last study period (2009) was specific by stabilization of central bars and their transformation to islands what affected the overall simplification trend of the Belá River pattern from braided to transitional wandering-braided one $[8,9,10]$. Lately gravel mining and river sediment replacing definitely support this trend in time when the opposite nature-based management approaches and challenges (channel renaturalization of the rare and unique river system in Slovakia - NATURA 2000, protected area) are the most desirable $[7,11,12,13,14]$. Similar development on the east Slovak the river Ondava and the Topl'a with decrease channel width from $87.6 \mathrm{~m}$ to $32.6 \mathrm{~m}$ and from $62.1 \mathrm{~m}$ to $27.2 \mathrm{~m}$ confirms the necessity to protect so vulnerable natural elements $[15,16,17,18]$. Responsible river management with protection from gravel mining and green approaches to reduction flood risk are essential for sustainable development of natural active channels. 


\section{References}

1. Kondolf, G.M., 1997. Hungry water: effects of dams and gravel mining on river channel. Environ. Manag. 21, 533-551.

2. Rinaldi, M.,Wyżga, B., Surian, N., 2005. Sediment mining in alluvial channels: physical effects and management perspectives. River Research and Application 21, 805-828.

3. Radecki-Pawlik A. 2002. Pobór żwiru i otoczaków z dna potoków górskich. Aura Ochrona Środowiska, Sigma-NOT, 3, s.17-19.

4. Wyżga B., Hajdukiewicz H., Radecki-Pawlik A., Zawiejska J. 2010. Eksploatacja osadów z koryt rzek górskich - skutki środowiskowe i procedury oceny. Gospodarka Wodna, Warszawa, Sigma-Not, 6, 243-249.

5. Mikuś P., Wyżga B., Radecki-Pawlik, Zawiejska J., Amirowicz A., Oglęcki P., 2016: Environment-friendly reduction of flood risk and infrastructure damage in a mountain river: case study of the Czarny Dunajec. Geomorphology, dx.doi.org/10.1016/j.geomorph.2015.11. Geomorphology 272, 43-54

6. Kidová, A., Lehotský, M., Rusnák, M. 2016: Morfologické zmeny a manažment divočiaco-migrujúceho vodného toku Belá. Rec. P. Pekárová, P. Pišút. In Geomorphologia Slovaca et Bohemica, 16 (2), s. 1-60. Dostupné na internete: http://www.asg.sav.sk/gfsb/v0162/GSeB_2_2016.pdf

7. Kidová, A., Lehotský, M., Rusnák, M. 2016: Geomorphic diversity in the braidedwandering Belá River, Slovak Carpathians, as a response to flood variability and environmental changes. In Geomorphology, 272, p. 137-149.

8. Kidová, A., Lehotský, M., Rusnák, M. 2017: Recent channel planform evolution of a braided-wandering river using multitemporal data and GIS (case study of the Belá River, Slovak Carpathians). In Acta Scientiarum Polonorum. Formatio Circumiectus, 16 (1), p. 247-259.

9. Kidová, A. 2010: Vývoj antropogénneho vplyvu na morfológiu koryta vodného toku príklad rieky Belej. In: Liga, J., Pavlovič, V., Strelková, M., Ríčiová, D., Cápay, M. (Eds.), Mladí vedci 2010: zborník vedeckých prác doktorandov, mladých vedeckých a pedagogických pracovníkov. Fakulta prírodných vied Univerzity Konštantína Filozofa, Nitra, $485-491$.

10. Kidová, A., Lehotský, M., 2012. Spatio-temporal morphological variability of the braided-wandering River Belá. Geografický Casopis 64 (4), 311-333 (Slovak, with English summary).

11. Lehotský, M., Kidová, A., Rusnák, M. 2015: Slovensko-anglické názvoslovie morfológie vodných tokov. In Geomorphologia Slovaca et Bohemica, 15 (1), s. 1-63. http://www.asg.sav.sk/gfsb/v0151/GSeB_1_2015.pdf

12. Lehotský, M., Rusnák, M., Kidová, A., Dudžák, J. 2018: Multitemporal assessment of coarse sediment connectivity along a braided-wandering river. In Land Degradation \& Development, 2018, vol. 29, no. 4, p. 1249-1261. (7.270 - IF2017). ISSN 1085-3278. https://onlinelibrary.wiley.com/doi/epdf/10.1002/ldr.2870

13. Lehotský, M., Frandofer, M., Novotný, J., Rusnák, M., Szmańda, J.B. 2013. Geomorphic/Sedimentary Responses of Rivers to Floods: Case Studies from Slovakia. In Lóczy D. [ed.]. Geomorphological Impacts of Extreme Weather. Dordrecht, Springer, 37-52.

14. Lehotský, M., Rusnák, M., Kidová, A. 2017. Application of remote sensing and the GIS in interpretation of river geomorphic response to floods. In Radecki-Pawlik A., 
Pagliara S., Hradecky J. [eds.]. Open Channel Hydraulics, River Hydraulic Structures and Fluvial Geomorphology : for engineers, geomorphologists and physical geographers. Portland, CRC Press, 388-399.

15. Rusnák, M., Lehotský, M., Kidová, A. 2016: Channel migration inferred from aerial Figgraphs, its timing and environmental consequences as responses to floods: a case study of the meandering Topl'a River, Slovak Carpathians. In Moravian Geographical Reports, vol. 24, no. 3, p. 32-43. ISSN 1210-8812. ,http:// www.geonika.cz/EN/research/ENMGRClanky/2016_3_RUSNAK.pdf

16. Rusnák, M., Lehotský, M. 2014. Time-focused investigation of river channel morphological changes due to extreme floods. Zeitschrift für Geomorphologie, 58(2), 251-266.

17. Rusnák, M., Sládek, J., Kidová, A., Lehotský, M. 2018. Template for high-resolution river landscape mapping using UAV technology. Measurement, 115, 139-151.

18. Radecki-Pawlik, Artur. 2015. Gravel mining in streams and rivers as one of the reasons of natural environment degradation. Acta Sci.Pol. Form. Cir. 14.3 (2015): 127-135. http://dx.doi.org/10.15576/ASP.FC/2015.14.3.127 